\title{
Impact of tick-borne Anaplasma phagocytophilum infections in calves of moose (Alces alces) in southern Norway
}

\author{
Irma Ražanske் $\dot{e}^{1}$, Olav Rosef $^{1,2}$, Jana Radzijevskaja $^{1}$, Ričardas Krikštolaitis $^{1}$ and Algimantas Paulauskas ${ }^{1(\mathbb{D})}$
}

${ }^{1}$ Vytautas Magnus University, Kaunas, Lithuania;

${ }^{2}$ Rosef Field Research Station, Mjåvatn, Norway

\begin{abstract}
The Gram-negative, obligate intracellular tick-transmitted pathogen Anaplasma phagocytophilum can cause acute febrile diseases in humans and domestic animals. The expansion of the tick Ixodes ricinus (Linnaeus, 1758) in northern Europe due to climate change is of serious concern for animal and human health. The aim of the present study was to investigate the impact of $A$. phagocytophilum infection in moose Alces alces (Linnaeus) calves by evaluating the carcass weights of infected and non-infected animals and examining animal tissues samples for co-infections with either species of Babesia Starcovici, 1893 or bacteria of the genus Bartonella. The carcasses of 68 free-ranging moose calves were weighed by hunters during the hunting seasons from 2014 to 2017 in two regions in southern Norway and spleen samples were collected. Anaplasma phagocytophilum was detected in moose sampled from locations infected with ticks with a prevalence of $82 \%(\mathrm{n}=46)$. The carcass weights of $A$. phagocytophilum-infected calves $(\mathrm{n}=$ 46) and non-infected $(\mathrm{n}=22)$ calves were compared. Although the average weight of infected calves $(45.6 \mathrm{~kg})$ was lower than that of non-infected calves $(46.5 \mathrm{~kg})$, the difference was not statistically significant. Three different variants of the bacterium 16S rRNA gene were identified. The average weight of animals infected with variant I was $49.9 \mathrm{~kg}$, whereas that of animals infected with variant III was $42.0 \mathrm{~kg}$, but the difference was not statistically significant $(\mathrm{p}=0.077)$. Co-infections of A. phagocytophilum with Bartonella spp. or with Babesia spp. were found in 20 and two calves, respectively. A triple infection was found in two calves. Sequence analysis of the 18S rRNA gene of Babesia-positive samples revealed the presence of Babesia cf. odocoilei (Emerson et Wright, 1970). Strains of Bartonella closely related to Bartonella bovis (Bermond, Boulouis, Heller, Laere, Monteil, Chomel, Sander, Dehio et Piemont, 2002) were identified based on phylogenetic analysis of the $g l t A$ and $r p o B$ genes. The loss of body mass in moose calves in the tick-infected site was probably influenced by multiple factors.
\end{abstract}

Keywords: Babesia spp., Bartonella spp., body condition, calf weight, co-infections

This article contains supporting information online at http://folia.paru.cas.cz/suppl/2021-68-023.pdf

In recent decades, the distribution and abundance of the tick Ixodes ricinus (Linnaeus) have increased in Europe (Medlock et al. 2013). Tick densities are likely to be strongly influenced by population density fluctuations in vertebrate host species and other ecological changes such as changes in land use, forest and wildlife management. This may lead to a high density of ticks in areas with free-ranging cervids (Wilson et al. 1988, Medlock et al. 2013, Paul et al. 2016). A high abundance of potential hosts is an important factor in tick expansion and in the potential for the spread of tickborne diseases (Gilbert 2010). Ticks can transmit different pathogens and often harbour more than one agent simultaneously (Madison-Antenucci et al. 2020).

Anaplasma phagocytophilum is a Gram-negative, obligate intracellular, tick-transmitted bacterium that may cause acute febrile tick-borne fever in humans (Strle 2004) and is also a causative agent of a well-known disease in domestic animals in several countries in Europe, Asia and America (Woldehiwet 2010). In domestic sheep, the disease is characterised by infected neutrophils, high fever, neutropenia, reduced milk yield, abortion, and reduced fertility (Woldehiwet and Scott 1993). The fever reaction may vary depending on the age of the animals, the variant of $A$. phagocytophilum involved, host species and immunological status of the host (Stuen et al. 2013a). Besides domestic ruminants, A. phagocytophilum has been identified in roe deer Capreolus capreolus Linnaeus, red deer Cervus elaphus Linnaeus (Alberdi et al. 2000, Stuen et al. 2013b, Razanske et al. 2019) and moose Alces alces Linnaeus (Puraite et al. 2015a).

One of the most important tick-borne infectious diseases in wild and domestic mammals is babesiosis (Hunfeld et al. 2008), which is caused by the infection of mammals by protists of the genus Babesia Starcovici, 1893, which in- 
vade erythrocytes (Beugnet and Moreau 2015). Babesiosis varies in severity from asymptomatic infections to anaemia with acute circulatory shock, depending on the host's immunity status and age, species of Babesia and the parasite load (Zintl et al. 2003).

Deer ked Lipoptena cervi Linnaeus, 1758 (common haematophagous parasites that feed primarily on cervids) is considered a potential vector for bacteria of the genus Bartonella Strong, O'Connor, Winkler et Steigerwalt, 1915 (see Hornok et al. 2011, Duodu et al. 2013). In the last few decades, $L$. cervi has shown a remarkable increase in abundance and is currently rapidly expanding its range northwards in Finland, Sweden and Norway (Välimäki et al. 2010).

Bartonella spp. are facultative intracellular, aerobic Gram-negative bacilli (Birtles and Raoult 1996) transmitted from host to host by a diverse range of haematogenous arthropod vectors; they are considered to be emerging pathogens in humans and animals (Boulouis et al. 2005). They have been isolated or detected in a wide range of wild and domestic mammals, and infections are often chronic or asymptomatic in their reservoir hosts (Chomel et al. 2009, Okaro et al. 2017).

The aim of the present study was to investigate the impact of $A$. phagocytophilum infection on moose calves by evaluating the carcass weights of infected and non-infected animals. The calf weights were registered by the hunters. Strains of $A$. phagocytophilum were identified to detect possible differences in their infectivity for calves of different weights. A further objective was to investigate and analyse co-infections with species of Babesia and Bartonella.

\section{MATERIALS AND METHODS}

\section{Sampling}

The carcasses of 68 free-ranging moose calves were weighed and spleen samples collected by hunters during the hunting season (October - December) from 2014 to 2017 in two areas of southern Norway. One study area $(\mathrm{n}=56$ animals) was located in six municipalities (Arendal, Froland, Grimstad, Nome, Tvedestrand and Vegårshei) within the distribution zone of Ixodes ricinus, where ticks are abundant during spring-autumn, whereas the other area in Øystre Slidre municipality $(n=12)$ is where ticks are either absent or rarely observed.

After evisceration, a piece of spleen about $5 \times 5 \mathrm{~cm}$ was taken from each carcass and placed in a separate plastic bag, with the site, date, weight and sex written on the bag, which was then put in a freezer. Later, the frozen samples were taken to the laboratory. They were thawed upon arrival at the laboratory before DNA extraction. In addition, the spleens of four calves found dead (Froland municipality), with acute pneumonia diagnosed by visual autopsy by a veterinarian in 2017, were also included for analyses of vector-borne infections.

\section{DNA extraction and molecular analyses}

DNA was extracted from approximately $10 \mathrm{mg}$ of each spleen (the piece used for DNA extraction was taken from the inner tissue layer) with the Genomic DNA Purification Kit (Thermo Fisher Scientific, Vilnius, Lithuania), according to the manufacturer's recommendations. DNA was dissolved in $100 \mu \mathrm{l}$ of sterile deionised water and stored at $-20{ }^{\circ} \mathrm{C}$ until PCR analysis. All samples were screened for the presence of DNA of Anaplasma phagocytophilum, Babesia spp. and Bartonella spp.

A real-time PCR was used to amplify a $98 \mathrm{bp}$ product from $A$. phagocytophilum (msp2 gene) and 214 bp product from Babesia spp. (18S rDNA), as previously described (Razanske et al. 2019). To amplify larger fragments for species and strain identification, nested PCRs targeting the 16S rRNA gene (546 bp) of A. phagocytophilum (Massung et al. 1998) and the 18S rRNA gene (380 bp) of Babesia spp. (Armstrong et al. 1998, Rar et al. 2005) were performed. For detection of Bartonella spp., conventional and nested PCR amplifications of partial gltA (379 bp) (Norman et al. 1995), rрoB (825 bp) (Renesto et el. 2001) genes and the 16S-23S rDNA ITS region ( $\sim 900$ bp) (Jensen et al. 2000, Kaewmongkol et al. 2011) were used (Table 1). All reactions were repeated three times. Detailed PCR protocols are presented in Table S1.

In all relevant amplifications, positive DNA of $A$. phagocytophilum from isolate N22 (KT070828), DNA of Babesia capreoli Enigk et Friedhoff, 1962 from isolate NB41 (KT279880) and Bartonella spp. DNA from isolate NT21 (MF491738) were used as positive controls in PCR reactions. Negative controls (distilled water without DNA) were included in all runs after every five experimental samples. To minimise the potential for contamination,

Table 1. PCR targets and primers used in this study for detection of Anaplasma phagocytophilum, Babesia spp. and Bartonella spp.

\begin{tabular}{|c|c|c|c|c|c|}
\hline Pathogen & $\begin{array}{l}\text { Target } \\
\text { gene }\end{array}$ & & $\begin{array}{l}\text { Oligonucleotide sequences (5'-3') } \\
\text { Forward }\end{array}$ & Reverse & Reference \\
\hline \multirow{2}{*}{$\begin{array}{l}\text { Anaplasma } \\
\text { phagocy- } \\
\text { tophilum }\end{array}$} & \multirow[t]{2}{*}{$\begin{array}{l}16 \mathrm{~S} \\
\text { rRNA }\end{array}$} & Outer primers & $\begin{array}{l}\text { CACATGCAAGTCGAACGGAT- } \\
\text { TATTC }\end{array}$ & $\begin{array}{l}\text { TTCCGTTAAGAAG- } \\
\text { GATCTAATCTCC }\end{array}$ & \multirow{2}{*}{ Massung et al. 1998} \\
\hline & & Inner primers & $\begin{array}{l}\text { AACGGATTATTCTTTATAGAACG- } \\
\text { GATTATTCTTTATAGCTTGCT }\end{array}$ & $\begin{array}{l}\text { GGCAGTATTAAAAGCAGCTC- } \\
\text { CAGG }\end{array}$ & \\
\hline \multirow{2}{*}{ Babesia spp. } & \multirow[t]{2}{*}{$\begin{array}{l}18 \mathrm{~S} \\
\text { rRNA }\end{array}$} & Outer primers & GACGGTAGGGTATTGGCCT & ATTCACCGGATCCACTCGATC & Rar et al. 2005, 2011 \\
\hline & & Inner primers & ATTACCCAATCCTGACACAGGG & $\begin{array}{l}\text { CCAACAAAATAGAACCAAA- } \\
\text { GTCCTAC }\end{array}$ & $\begin{array}{l}\text { Armstrong et al. } 1998, \\
\text { Rar et al. } 2011\end{array}$ \\
\hline \multirow{4}{*}{$\begin{array}{l}\text { Bartonella } \\
\text { spp. }\end{array}$} & \multirow[t]{2}{*}{ ITS } & Outer primers & ACCTCCTTTCTAAGGATGAT & СTCTTTCTTCAGATGATGATCC & Kaewmongkol et al. 2011b \\
\hline & & Inner primers & СТCTTTCTTCAGATGATGATCC & GCGGTTAAGCTTCCAATCATA & $\begin{array}{l}\text { Jensen et al. } 2000 \\
\text { Kaewmongkol et al. } 2011 \mathrm{~b}\end{array}$ \\
\hline & gltA & & GGGGACCAGCTCATGGTGG & AATGCAAAAAGAACAGTAAA & Norman et al. 1995 \\
\hline & rрoB & & CGCATTGGYTTRCTTCGTAT & GTRGAYTGATTRGAACGYTG & Renesto et al. 2001 \\
\hline
\end{tabular}


Table 2. Anaplasma phagocytophilum infection and co-infections with Bartonella spp. and Babesia spp. detected in moose calves.

\begin{tabular}{|c|c|c|c|c|c|c|c|c|}
\hline Alces alces & $\begin{array}{c}\text { Anaplasma } \\
\text { phagocytophilum }\end{array}$ & Bartonella spp. & Babesia spp. & $\begin{array}{l}\text { Double infection } \\
\text { (A. phagocy- } \\
\text { tophilum }+ \\
\text { Bartonella } \text { spp.) }\end{array}$ & $\begin{array}{l}\text { Double infection } \\
\text { (A. phagocy- } \\
\text { tophilum }+ \\
\text { Babesia } \text { spp.) }\end{array}$ & $\begin{array}{l}\text { Double infection } \\
\text { (Bartonella } \mathrm{spp} . \\
+ \text { Babesia } \text { spp.) }\end{array}$ & $\begin{array}{l}\text { Triple infection (A. } \\
\text { phagocytophilum } \\
\text { + Bartonella spp. } \\
\text { + Babesia } \text { spp.) }\end{array}$ & $\begin{array}{l}\text { Non- infected } \\
\text { animals }\end{array}$ \\
\hline$n$ & $n$ & $n$ & $n$ & $n$ & $n$ & $n$ & $n$ & $n$ \\
\hline \multirow[t]{2}{*}{68} & 46 & 27 & 5 & 20 & 2 & 1 & 2 & 17 \\
\hline & $67.6 \%$ & $39.7 \%$ & $7.4 \%$ & $29.4 \%$ & $2.9 \%$ & $1.4 \%$ & $2.9 \%$ & $25.0 \%$ \\
\hline $4^{*}$ & 4 & 2 & 0 & 2 & 0 & 0 & 0 & 0 \\
\hline
\end{tabular}

*- Samples of four calves found dead with acute pneumonia signs. Carcass weight was not recorded.

DNA extractions, PCR, nested PCR and agarose gel electrophoresis were performed in separate rooms and filter tips were used in these processes.

The PCR amplification products were separated by gel electrophoresis in $0.5 \times$ TAE buffer (Thermo Fisher Scientific) using $1.5 \%$ agarose at $100 \mathrm{~V}$ for $60 \mathrm{~min}$, stained with ethidium bromide and visualised under UV light. The summarised results of nested and conventional PCR are provided in Table S2. A sample whose amplification has been confirmed at least two times is considered positive. Amplicons obtained from amplification were purified using the GeneJET Gel Extraction Kit (Thermo Fisher Scientific) following the manufacturer's instructions. Purified PCR products were sent to a sequencing service (Macrogen, Amsterdam, Netherlands). The obtained sequences of species of Babesia, Bartonella and $A$. phagocytophilum were compared with sequences available from the GenBank database (www.ncbi.nlm.nih.gov) using the BLASTn tool of the National Center for Biotechnology Information. Phylogenetic analyses were conducted using MEGA X software (Kumar et al. 2018).

\section{Statistical analysis}

Statistical analysis was performed to assess the differences in moose weights. First the Kolmogorov-Smirnov Z test was performed, which showed that the data followed normal distribution ( $Z=0.086, p=0.200)$. This allowed the Student's t-test to be used to assess differences in moose weights. The statistical analysis was performed using IBM SPSS Statistics 19. The decision about statistically significant differences was accepted at a significance level of $\mathrm{P}=0.05$. The influence of infection status and municipality on body mass was evaluated using the univariate General Linear Model (GLM), with body mass as a dependent variable, $A$. phagocytophilum infection (positive/negative) as an independent variable, and municipality as a random factor.

\section{RESULTS}

\section{Detection of agents in moose calves}

Of the 68 spleen samples tested, 46 (68\%) were positive for Anaplasma phagocytophilum, 27 (40\%) for Bartonella spp., and five (7\%) for Babesia spp. Co-infection of $A$. phagocytophilum with Bartonella spp. was found in 20 animals. In two calves, co-infection of $A$. phagocytophilum with Babesia spp. was detected. A triple infection was found in two calves (Table 2).

Anaplasma phagocytophilum was detected only in animals sampled from locations infected with ticks with a prevalence of $82 \%$ (46 out of 56). A total of 33 positive samples for $A$. phagocytophilum were sequenced. Sequence analysis revealed three different $16 \mathrm{~S}$ rRNA gene variants: variants I, II and III (Table 3) with $100 \%$ identity to sequences deposited in the GenBank database (MK239931, MH794246, KY404197, MN170724, KM215240, FJ788513, MK814412, MH122889, MG976767) of different mammalian species (Canis lupus familiaris Linnaeus, Equus caballus Linnaeus, Capreolus capreolus, Homo sapiens Linnaeus) and Ixodes ricinus ticks from different countries (South Korea, Slovenia, Germany, Spain, Poland, South Africa). Four calves with pneumonia tested by PCR were all positive for A. phagocytophilum. Two harboured $A$. phagocytophilum $16 \mathrm{~S}$ rRNA variant I and two harboured variant III. Sequences of $A$. phagocytophilum from this study were deposited in the GenBank database under accession numbers MT221232 (this sequence is representative of 16 samples sequenced in this study), MT221233 (representative of one sample) and MT221234 (representative of 16 other samples).

All Babesia-infected animals were from the area where I. ricinus is present. Sequence analysis (277-296 base pairs of the $18 \mathrm{~S}$ rRNA gene) of three amplicons revealed 99.3-100\% identity, with GenBank entries attributed to Babesia odocoilei Emerson et Wright, 1970 (MN563153, MN563145, KY242389), B. cf. odocoilei (MK612774, MK612775, KU351827, KU351828) or Babesia sp. 'deer clade' (MG344773, MG344776) of wild ruminant origin (Cervus elaphus, Dama dama Linnaeus) from different European countries (Czech Republic, Germany, Norway, UK) (Fig. 1). Sequences of Babesia isolates from this study were deposited in the GenBank database under accession numbers KT279884, MW759308 and MW759309.

Bartonella spp. was detected in animals from both study areas. GltA gene sequences differed from each other in one nucleotide position $(\mathrm{C} / \mathrm{T})$ and were closely related to the strains of Bartonella bovis of Bermond et al. (2002) (showed a 98-100\% sequence similarity) (Fig. 2). Obtained partial sequences of $r p o B$ gene differed in single nucleotide positions (A/G) and showed $98-99 \%$ identity to strains of $B$. bovis (Fig. 3). Sequences of $r p o B$ of isolates of Bartonella from this study were deposited in the GenBank database with accession numbers MW767937 (this sequence is representative of two samples sequenced in this study) and MW767938 (representative of six samples), and sequences for glt $A$ gene were deposited with accession numbers MW767939 (representative of three samples) and MW767940 (representative of five samples).

\section{Statistical analysis}

The mean carcass weight for calves from the area where I. ricinus ticks are abundant was $45.7 \mathrm{~kg}(\sigma=13.3)(\mathrm{n}=56$, 


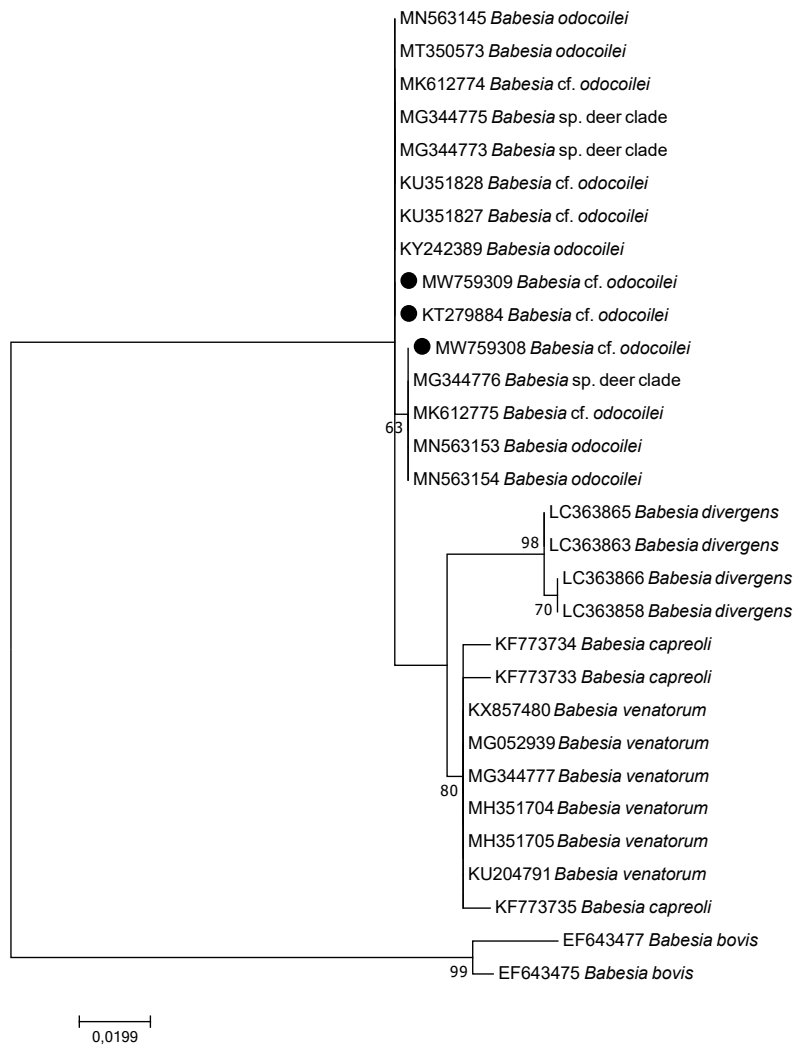

Fig. 1. Phylogenetic tree of isolates of Babesia Starcovici, 1893 isolated in the present study $(\bullet)$, based on fragments of the 18S rRNA gene, generated using the Maximum likelihood method in MEGA X software (1,000 replicates; bootstrap values indicated at the nodes). Babesia bovis (Babes, 1892) was used as outgroup.

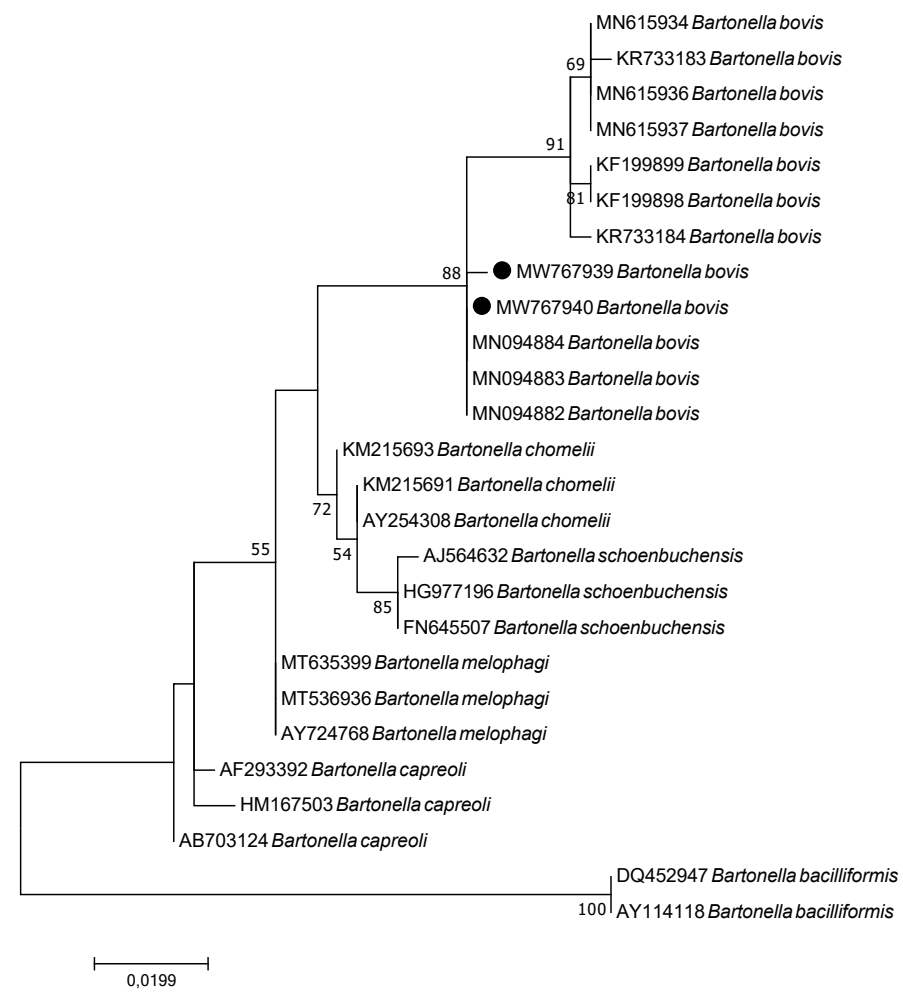

Fig. 2. Phylogenetic tree of isolates of Bartonella bacteria obtained in this study $(\bullet)$, based on fragments of the $g l t A$ gene and generated using the Maximum likelihood method in MEGA X software (1,000 replicates; bootstrap values indicated at the nodes). Bartonella bacilliformis was used as outgroup. 


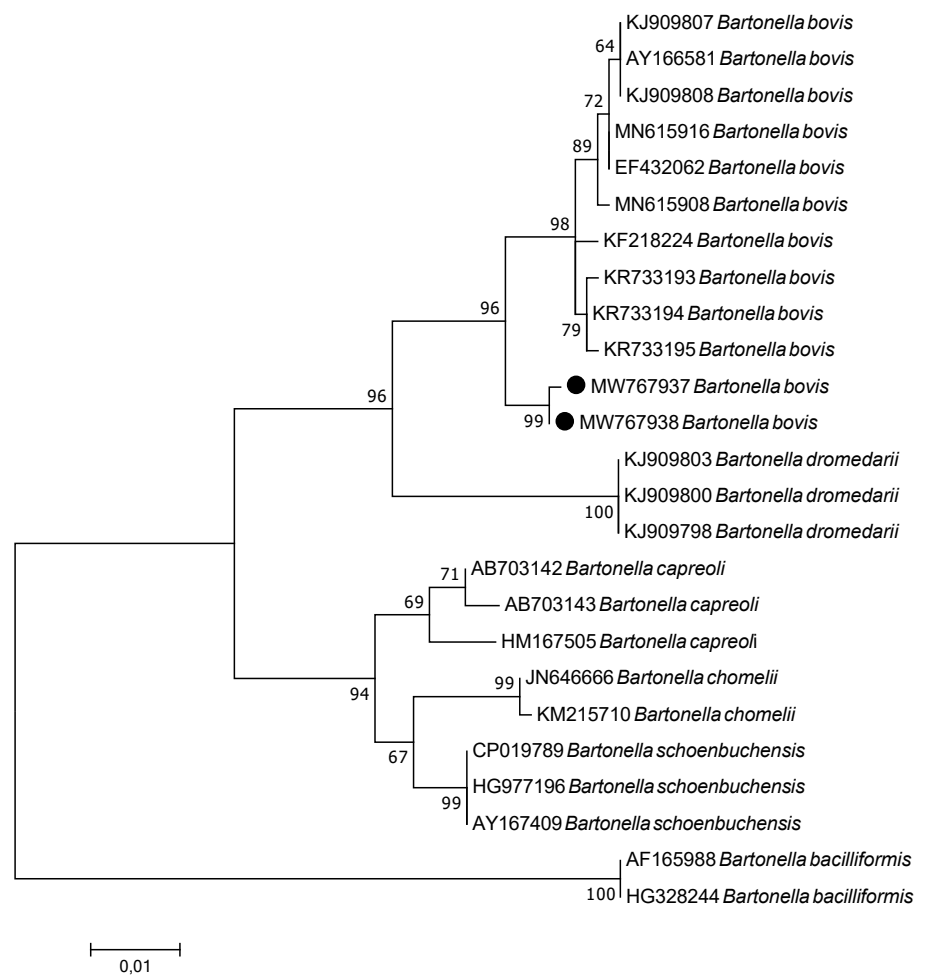

Fig. 3. Phylogenetic tree of isolates of Bartonella bacteria obtained in this study $(\bullet)$, based on fragments of the rpoB gene and generated using the Maximum likelihood method in MEGA X software (1,000 replicates; bootstrap values indicated at the nodes). Bartonella bacilliformis was used as outgroup.

ranging from $15.4 \mathrm{~kg}$ to $66.0 \mathrm{~kg}$ ), whereas for those from the area where ticks are known to be absent the mean carcass weight was $69.3 \mathrm{~kg}(\sigma=11.3)(\mathrm{n}=12$, ranging from $58.0 \mathrm{~kg}$ to $91.0 \mathrm{~kg}$ ).

The carcass weights of $A$. phagocytophilum-infected calves $(\mathrm{n}=46)$ and non-infected $(\mathrm{n}=10)$ calves from the tick-infected area were compared. The non-infected calves had an average weight of $46.5 \mathrm{~kg}(\sigma=14.2)$, whereas the average weight of infected calves was $45.6 \mathrm{~kg}(\sigma=13.3)$. The difference was not statistically significant $(\mathrm{t}=0.196$, $\mathrm{p}=0.845$ ).

Infected animals were divided into three groups based on the 16S rRNA variant of $A$. phagocytophilum and the average weight of carcasses in each group was calculated (Table 3). A comparison of weights was only performed with calves infected with 16S rRNA variants I and III of $A$. phagocytophilum, since just one calf was infected with variant II. The average weight of animals infected with variant I was $49.9 \mathrm{~kg}(\sigma=10.5)$, whereas that of animals infected with variant III was $42.0 \mathrm{~kg}(\sigma=13.8)$. However, the difference was not statistically significant $(\mathrm{t}=1.84, \mathrm{p}=0.077)$.

Table 3. 16S rRNA gene variants of Anaplasma phagocytophilum and average weight of moose calves.

\begin{tabular}{lccccc}
\hline $\begin{array}{l}\text { GenBank } \\
\text { accession }\end{array}$ & Variant & & \multicolumn{2}{c}{ Variable positions } & Number of \\
\cline { 3 - 6 } number & & 4 & 95 & $\begin{array}{c}\text { Average } \\
\text { weight }\end{array}$ \\
\hline MT221232 & I & A & C & 16 & $49.9 \mathrm{~kg}$ \\
MT221233 & II & - & A & 1 & $48.0 \mathrm{~kg}$ \\
MT221234 & III & G & - & 16 & $42.0 \mathrm{~kg}$ \\
\hline
\end{tabular}

The influence of infection status and municipality on body mass evaluated using univariate GLM showed that status of infection with $A$. phagocytophilum does not have a statistically significant $(\mathrm{p}=0.669)$ influence on moose mass weight either when municipality status is a random factor or when municipality status is a fixed factor).

\section{DISCUSSION}

The highest prevalence of Anaplasma phagocytophilum in Ixodes ricinus has been shown to occur in areas with the highest cervid density (Rosef et al. 2009, Mysterud et al. 2013). The infection rate of $A$. phagocytophilum in I. rici$n u s$ in Norway ranges from $0 \%$ to $20 \%$ (Rosef et al. 2008, Tveten 2014, Henningsson et al. 2015).

Anaplasma phagocytophilum causes disease and economic losses in livestock (Woldehiwet 2006). Tick-borne fever is considered a major problem in livestock production, leading to mortality, with lambs at particular risk (Stuen and Bergstrøm 2001), and reducing the body growth of lambs (Stuen et al. 2002, Grøva et al. 2011). Tick-borne fever among wild cervids has been diagnosed in a moose calf and in one roe deer calf from southern Norway, both of which died from septicaemia with bacteria regarded as opportunistic pathogens (Jenkins et al. 2001, Stuen et al. 2001). A possible effect of infection with A. phagocytophilum on moose weights has previously been suggested $(\mathrm{Pu}-$ raite et al. 2015a).

The present study showed that four calves with severe clinical pneumonia diagnosed by autopsy were infected with two different $A$. phagocytophilum strains. Lung inflammation was found in two calves infected with variant 
I and two other calves infected with variant III. It appears possible that both variants can cause secondary lung infection. Molecular characterisation of strains of A. phagocytophilum showed that different variants of the $16 \mathrm{~S}$ rRNA gene previously detected in various species of animals in Europe, Asia, Africa and the United States are currently circulating in the moose population in Norway.

In the present study, no effect of $A$. phagocytophilum on moose calf body mass was identified. The findings showed that there was no statistically significant difference in body mass between calves infected with $A$. phagocytophilum and those not infected, and the effect of infection status was not significant when municipality was included either as a significant random factor or as a fixed factor.

In previous studies conducted in Norway, $A$. phagocytophilum DNA has been found in moose (infection rate of $31-70 \%)$, roe deer (52-82\%), red deer (51-94\%) and sheep (38\%) (Stuen et al. 2013b, Puraite et al. 2015a, Razanske et al. 2019, Stigum et al. 2019). Antibodies against $A$. phagocytophilum and DNA of its different variants have been shown to persist in sheep, horses, dogs, cattle, moose, roe deer and red deer (Stuen et al. 2013a, Woldehiwet 2010). A high prevalence of seropositivity $(79 \%)$ in moose serum is reported from tick-infected areas (Milner and van Beest 2013).

Among the several factors discussed to have influenced the lower calf carcass weight are the reduction in food quality and quantity due to warmer summer temperatures, the reduced area of forest consisting of early successional stages (Wam et al. 2010), and a negative correlation between body condition and endoparasite densities (Davidson et al. 2015). Body mass and the reproductive performance index in the southern and south-eastern regions of Norway have fallen in the last 20-25 years (Wam et al. 2010, van Beest et al. 2012). Historical registrations of calf carcass weights show a decrease from $59 \mathrm{~kg}(\mathrm{n}=410)$ to $49 \mathrm{~kg}(\mathrm{n}=170)$ in Aust-Agder county between 2000 and 2017 (Meland and Roer 2018).

The data from the present study showed a lower mean carcass weight $(45.7 \mathrm{~kg})$ in the study area (Arendal, Froland, Grimstad, Nome, Tvedestrand and Vegårshei municipalities) where ticks are abundant. In Øystre Slidre (most non-infected calves were from this municipality) where ticks are either absent or rarely observed (Climate change, impacts and vulnerability in Europe 2016, 2017), the mean calf weights were $63.6 \mathrm{~kg}(\mathrm{n}=64)$ in 1999 and $64.2 \mathrm{~kg}(\mathrm{n}$ $=30$ ) in 2014, which indicates no reduction in calf weight (Puraite et al. 2015a). For years, local hunters have reported low numbers of moose calves on the island of Øland in Sweden during the autumn hunt, and it has been suggested that infection with $A$. phagocytophilum has affected their health and survival (Malmsten and Dali 2014). Furthermore, dead calves with acute pneumonia infected with $A$. phagocytophilum have been registered (Malmsten 2017).
In Europe, babesiosis has been reported in humans and in some domestic and free-living mammals (Herwaldt et al. 2003), and was first documented in moose in Norway (Puraite et al. 2015b). Infection with Babesia divergens M'Fadyean et Stockman, 1911 in cattle is widespread in the coastal areas of Norway (Hasle et al. 2010). Isolates of Babesia were detected in four moose calves infected with A. phagocytophilum and in one calf in which A. phagocytophilum was not detected (Table 2). Three samples positive for Babesia spp. were sequenced and all belonged to Babesia cf. odocoilei.

Various species of Bartonella have been found to be specifically adapted to distinct mammalian hosts, causing long-term intraerythrocytic infections, and have been isolated or detected in a wide range of wild and domestic animals (Chomel et al. 2009). The present study showed that bacteria of Bartonella was detected in moose calves infected with $A$. phagocytophilum (Table 2) and in non-infected calves. Bartonella sp. were detected with an overall prevalence of $40 \%$ and the identified strains belonged to a B. bovis clade. In a previous study, two lineages of Bartonella were detected in Norwegian cervids and deer keds based on analysis of $16 \mathrm{~S}-23 \mathrm{~S}$ rDNA ITS region and gltA gene sequences. Sacristán et al. (2020) found that prevalence with bacteria of Bartonella ranged in moose from $70.6 \%$ to $92.9 \%$ and strains of Bartonella derived from moose were closely related to $B$. bovis. However, two lineages of Bartonella were detected in moose in other studies conducted in Norway (Duodu et al. 2013) and Finland (Korhonen et al. 2015, Pérez Vera et al. 2016).

It can be concluded that variation in moose calf body mass observed in the present study was probably influenced by multiple factors. The spread of infected ticks to new territories will result in higher infection of moose that are not adapted to the bacteria. These factors may play a role in lower carcass weights and higher calf mortality. In the present study, a high prevalence of $A$. phagocytophilum was found in moose calves from tick-infected areas. Three different strains A. phagocytophilum were detected by sequencing part of the $16 \mathrm{~S}$ rRNA gene. Although not proven in this study, the possible effect of infection with A. phagocytophilum on moose carcass weights should be further investigated. Double and triple co-infections with $A$. phagocytophilum, Babesia spp. and Bartonella spp. were detected.

Acknowledgements. We thank Øyvind Froland for his excellent help in collecting spleen samples during hunting seasons, and Aust-Agder Fylkeskommune for financial support.

Author contribution. Irma Ražanskè: methodology, investigation, writing - review \& editing. Olav Rosef: conceptualisation, resources, writing - original draft. Jana Radzijevskaja: conceptualisation, methodology, writing - review \& editing. Ričardas Krikštolaitis: statistical analysis, writing - review \& editing. Algimantas Paulauskas: conceptualisation, resources, writing - review \& editing. All authors read and approved the final manuscript. 


\section{REFERENCES}

Alberdi M.P., Walker A.R., Urquhart K.A. 2000: Field evidence that roe deer (Capreolus capreolus) are a natural host for Ehrlichia phagocytophila. Epidemiol. Infect. 124: 315-323.

Armstrong P.M., Katavolos P., Caporale D.A., Smith R.P., Spielman A., Telford S.R. III 1998: Diversity of Babesia infecting deer ticks (Ixodes dammini). Am. J. Trop. Med. Hyg. 58: 739-742.

Beugnet F., Moreau Y. 2015: Babesiosis. Rev. Sci. Tech. 34: 627-639.

Birtles R.J., Raoult D. 1996: Comparison of partial citrate synthase gene $(\mathrm{glt} A)$ sequences for phylogenetic analysis of Bartonella species. Int. J. Syst. Bacteriol. 46: 891-897.

Boulouis H.J., Chang C.C., Henn J.B., Kasten R.W., Chomel B.B. 2005: Factors associated with the rapid emergence of zoonotic Bartonella infections. Vet. Res. 36: 383-410.

Chomel B.B., Boulouis H.J., Breitschwerdt E.B., Kasten R.W., Vayssier-Taussat M., Birtles R.J., Koehler J.E., DEHIO C. 2009: Ecological fitness and strategies of adaption of Bartonella species to their hosts and vectors. Vet. Res. 40: 29.

Climate Change, impacts and vulnerability in Europe 2016; 2017: The Report, https://www.eea.europa.eu/data-andmaps/indicators/vector-borne-diseases-2/assessment, 9/2020.

Davidson R.K., Ličina T, Gorini L., Milner J.M. 2015: Endoparasites in a Norwegian moose (Alces alces) population - faunal diversity, abundance and body condition. Int. J. Parasitol. Parasites Wildl. 4: 29-36.

Duodu S., Madslien K., Huelm E., Molin Y., PaziewsKa-Harris A., Harris P.D., Colquhoun D.J., Ytrehus B. 2013: Bartonella infections in deer keds (Lipoptena cervi) and moose (Alces alces) in Norway. Appl. Environ. Microbiol. 79: $322-327$.

Gilbert L. 2010: Altitudinal patterns of tick and host abundance: a potential role for climate change in regulating tick-borne diseases? Oecologia 162: 217-225.

Grøva L., Olesen I., Steinshamn H., Stuen S. 2011: Prevalence of Anaplasma phagocytophilum infection and effect on lamb growth. Acta Vet. Scand. 53: 1-7.

Hasle G., Buune G.A., Christensson D., Rød K.H., Whist A.C., LeinaAs H.P. 2010: Detection of Babesia divergens in southern Norway by using an immunofluorescence antibody test in cow sera. Acta Vet. Scand. 52: 55.

Henningsson A.J., Hvidsten D., Kristiansen B.E., MaTussek A., Stuen S., Jenkins A. 2015: Detection of Anaplasma phagocytophilum in Ixodes ricinus ticks from Norway using a realtime PCR assay targeting the Anaplasma citrate synthase gene glt $A$. BMC Microbiol. 15: 153.

Herwaldt B.L., Caccio S., Cherlinzoni F., Aspöck H., Slemenda S.B., Piccaluga P., Martinelli G., Edelhofer R., Hollenstein U., Poletti G., Pampiglione S., LöschenBerger K., Tura S., Pieniazek N.J. 2003: Molecular characterization of a non-Babesia divergens organism causing zoonotic babesiosis in Europe. Emerg. Infect. Dis. 9: 942-948.

Hornok S., de la Fuente J., Biró N., Fernández de Mera I.G., Meli M.L., Elek V., Gönczi E., Meili T., Tánczos B., Farkas R., Lutz H., Hofmann-Lehmann R. 2011: First molecular evidence of Anaplasma ovis and Rickettsia spp. in keds (Diptera: Hippoboscidae) of sheep and wild ruminants. Vect. Borne Zoon. Dis. 11: 1319-1321.

Hunfeld K.P., Hildebrandt A., Gray J.S. 2008: Babesiosis: recent insights into an ancient disease. Int. J. Parasitol. 38: 12191237.

Jenkins A., Handeland K., Stuen S., Schouls L., van de Pol I., Meen R.T., Kristiansen B.E. 2001: Ehrlichiosis in a moose calf in Norway. J. Wildl. Dis. 37: 201-203.
Jensen W.A., Fall M.Z., Rooney J., Kordick D.L., BREITSCHWERDT E.B. 2000: Rapid identification and differentiation of Bartonella species using a single step PCR assay. J. Clin. Microbiol. 38: 1717-1722.

Kaewmongkol G., Kaewmongkol S., Owen H., Fleming P.A., Adams P.J., Ryan U., Irwin P.J., Fenwick S.G. 2011b: Candidatus Bartonella antechini: a novel Bartonella species detected in fleas and ticks from the yellow-footed antechinus (Antechinus flavipes), an Australian marsupial. Vet. Microbiol. 149: 517-521.

Kaewmongkol S., Kaewmongkol G., Burmej H., Bennett M.D., Fleming P.A., Adams P.J. 2011a: Diversity of Bartonella species detected in arthropod vectors from animals in Australia. Comp. Immunol. Microbiol. Infect. Dis. 34: 411-417.

Korhonen E.M., Pérez Vera C., Pulliainen A.T., Sironen T., Aaltonen K., Kortet R., Härkönen L., Härkönen S., Paakkonen T., Nieminen P., Mustonen A.M., Ylönen H., VAPAlahti O. 2015: Molecular detection of Bartonella spp. in deer ked pupae, adult keds and moose blood in Finland. Epidemiol. Infect. 143: 578-585.

Kumar S., Stecher G., Li M., Knyaz C., Tamura K. 2018: MEGA X: Molecular evolutionary genetics analysis across computing platforms. Mol. Biol. Evol. 35: 1547-1549.

Madison-Antenucci S., Kramer L.D., Gebhardt L.L., KauFFMAN E. 2020: Emerging tick-borne diseases. Clin. Microbiol. Rev. 33: e00083-18.

Malmsten J. 2017: Summer death and low carcass weights in moose calves in South Sweden. Hjorteviltet 1: 83-84. (In Swedish.)

Malmsten J., DAli A.M. 2014: Reproductive failure in moose (Alces alces) due to embryonic mortality and unfertilized oocytes. Acta Theriol. 59: 449-455.

Massung R.F., Slater K., Owens J.H., Nicholson W.L., Mather T.N., Solberg V.B., Olson J.G. 1998: Nested PCR assay for detection of granulocytic ehrlichiae. J. Clin. Microbiol. 36: 1090-1095.

Medlock J.M., Hansford K.M., Bormane A., Derdakova M., Estrada-Peña A., George J.C., Golovljova I., Jaenson T.G., Jensen J.K., Jensen P.M., Kazimirova M., Oteo J.A., Papa A., Pfister K., Plantard O., Randolph S.E., Rizzoli A., Santos-Silva M.M., Sprong H., Vial L., HenDRICKX G., ZELler H., VAN BorTel W. 2013: Driving forces for changes in geographical changes in geographical distribution of Ixodes ricinus ticks in Europe. Parasit. Vectors. 6: 1.

Meland M., Roer R. 2018: Moose and red deer in Aust-Agder 2018. Fauna report. 1: 1-74. (In Norwegian.)

Milner J.M., VAN BeEst F.M. 2013: Ecological correlates of a tick-borne disease, Anaplasma phagocytophilum, in moose in southern Norway. Eur. J. Wildl. Res. 59: 399-406.

Mysterud A., Easterday W.R., Qviller L., Viljugrein H., YTREHUS B. 2013: Spatial and seasonal variation in the prevalence of Anaplasma phagocytophilum and Borrelia burgdorferi sensu lato in questing Ixodes ricinus ticks in Norway. Parasit. Vectors 6: 187.

Norman A.F., Regnery R., Jameson P., Greene C., Krause D.C. 1995: Differentiation of Bartonella-like isolates at the species level by PCR-restriction fragment length polymorphism in the citrate synthase gene. J. Clin. Microbiol. 33: 1797-1803.

Okaro U., Addisu A., Casanas B., Anderson B. 2017: Bartonella species, an emerging cause of blood-culture-negative endocarditis. Clin. Microbiol. Rev. 30: 709-746.

Paul R.E.L., Cote M., Le Naour E., Bonnet S.I. 2016: Environmental factors influencing tick densities over seven years in a French suburban forest. Parasit. Vectors 9: 309.

Pérez Vera C., Aaltonen K., Spillmann T., Vapalahti O., Sironen T. 2016: Geographic distribution and molecular diver- 
sity of Bartonella spp. infections in moose (Alces alces) in Finland. J. Wildl. Dis. 52: 209-216.

Puraite I., Rosef, O., Paulauskas A., Radzijevskaja J. 2015a: Anaplasma phagocytophilum infection in moose (Alces alces) in Norway. Microbes Infection 17: 823-828.

Puraite I., Rosef O., Radzijevskaja J., Lipatova I., Paulauskas A. 2015b: The first detection of species of Babesia starcovici, 1893 in moose, Alces alces (Linnaeus), in Norway. Folia Parasitol. 63: 009.

Rar V.A., Epikhina T.I., Livanova N.N., Panov V.V. 2011: Genetic diversity of Babesia in Ixodes persulcatus and small mammals from North Ural and West Siberia, Russia. Parasitology 138: $175-182$.

Rar V.A., Fomenko N.V., Dobrotvorsky A.K., Livanova N.N., Rudakova S.A., Fedorov E.G., Astanin V.B., MorozovA O. 2005: Tickborne pathogen detection Western Siberia, Russia. Emerg. Infect. Dis. 11: 1708-1715.

Razanske I., Rosef O., Radzijevskaja J., Bratchikov M., Griciuviene L., Paulauskas A. 2019: Prevalence and co-infection with tick borne Anaplasma phagocytophilum and Babesia spp. in red deer (Cervus elaphus) and roe deer (Capreolus capreolus) in southern Norway. Int. J. Parasitol. Parasites Wildl. 8: $127-134$

Renesto P., Gouvernet J., Drancourt M., Roux V., Raoult D. 2001: Use of rрoB gene analysis for detection and identification of Bartonella species. J. Clin. Microbiol. 39: 430-437.

Rosef O., Paulauskas A., Radzijevskaja J. 2009: Prevalence of Borrelia burgdorferi sensu lato and Anaplasma phagocytophilum in questing Ixodes ricinus ticks in relation to the density of wild cervids. Acta Vet. Scand. 51: 47.

Rosef O., Radzijevskaja J., Paulauskas A., Haslek ̊̊s C. 2008: The prevalence of Anaplasma phagocytophilum in host-seeking Ixodes ricinus ticks in Norway. Clin. Microbiol. Infect. 15: 43-45.

Sacristán C., das Neves C.G., Suhel F., Sacristán I., Tengs T., Hamnes I.S., Madslien K. 2020: Bartonella spp. detection in ticks, Culicoides biting midges and wild cervids from Norway. Transbound. Emerg. Dis. 68: 941-951.

Stigum V., JaArsma R., Sprong H., Rolandsen C.M., MysTERUD A. 2019: Infection prevalence and ecotypes of Anaplasma phagocytophilum in moose Alces alces, red deer Cervus elaphus, roe deer Capreolus capreolus and Ixodes ricinus ticks from Norway. Parasit. Vectors 12: 1.

Strle F. 2004: Human granulocytic ehrlichiosis in Europe. Int. J. Med. Microbiol. 293: 27-35.
Stuen S., Bergström K. 2001: Serological investigation of granulocytic Ehrlichia infection in sheep in Norway. Acta Vet. Scand. 42: 331-338.

Stuen S., Bergström K., Palmér E. 2002: Reduced weight gain due to subclinical Anaplasma phagocytophilum (formerly Ehrlichia phagocytophila) infection. Exp. Appl. Acarol. 28: 209-215.

Stuen S., Engvall E.O., van de Pol I., Schouls L.M. 2001: Granulocytic ehrlichiosis in a roe deer calf. J. Wildl. Dis. 37: 614-616.

Stuen S., Granquist E., Silaghi C. 2013a: Anaplasma phagocytophilum - a widespread multi-host pathogen with highly adaptive strategies. Front. Cel. Infect. Microbiol. 3: 31.

Stuen S., Pettersen K.S., Granquist E.G., Bergström K., Bown K.J., Birtles R.J. 2013b: Anaplasma phagocytophilum variants in sympatric red deer (Cervus elaphus) and sheep in southern Norway. Ticks Tick Borne Dis. 4: 197-201.

Tveten A.K. 2014: Prevalence and diversity among Anaplasma phagocytophilum strains originating from Ixodes ricinus ticks from Northwest Norway. J. Pathog. 2014: 824897.

Välimäki P., Madslien K., Malmsten J., Härkönen L., Härkönen S., Kaitala A., Kortet R., LaAKSOnen S., Mehl R., Redford L., Ylönen H., Ytrehus B. 2010: Fennoscandian distribution of an important parasite of cervids, the deer ked (Lipoptena cervi), revisited. Parasitol Res. 107: 117-125.

Van Beest F.M., Van Morter B., Milner J.M. 2012: Temperature-mediated habitat use and selection by a heat-sensitive northern ungulate. Anim. Behav. 84: 723-735.

Wam H.K., Hueljord O., Solberg E.J. 2010: Differential forage use makes carrying capacity equivocal on ranges of Scandinavian moose (Alces alces). Can. J. Zool. 88: 1179-1191.

Wilson M.L., Telford S.R., Piesman J., Spielman A. 1988: Reduced abundance of immature Ixodes dammini (Acari: Ixodidae) following elimination of deer. J. Med. Entomol. 25: 224-228.

Woldehiwet Z. 2006: Anaplasma phagocytophilum in ruminants in Europe. Ann. N.Y. Acad. Sci. 1078: 1823-1834.

Woldehiwet Z. 2010: The natural history of Anaplasma phagocytophilum. Vet. Parasitol. 167: 108-122.

Woldehiwet Z. and Scott G.R. 1993: Tick-borne (pasture) fever. In: Z. Woldehiwet, M. Ristic (Eds.), Rickettsial and Chlamydial Diseases of Domestic Animals. Pergamon, Oxford, pp. 233-254.

Zintl A., Mulcahy G., Skerrett H.E., Taylor S.M., Gray J.S. 2003: Babesia divergens: a bovine blood parasite of veterinary and zoonotic importance. Clin. Microbiol. Rev. 16: 622-636. 